JELTL (Journal of English Language Teaching and Linguistics) e-ISSN: 2502-6062, p-ISSN: 2503-1848

2018, Vol. 3 (2)

www.jeltl.org

\title{
Communicative Language Teaching in the Moroccan EFL Classroom
}

\author{
Hanae AIT HATTANI \\ Faculty of arts and human sciences Sais, Fez \\ Sidi Mohamed Benabdelah University, Morroco \\ email: aithanae@gmail.com
}

\begin{abstract}
Today, communities are increasingly facing rapid and profound changes and tensions that affect the social, economic, and political aspects of life. The role of education has also become questionable in the millennial era. A matter of fact, $21^{\text {st }}$ century education requires a gradual shift in curriculum construction focusing on the transferable competencies that learners need to develop in instructional settings. In today's knowledge-based, types of skills and competencies that students need to gain are different from in the past. Emphasizing the communicative competence is one of the most influential developments in language education. The implementation of communicative activities in EFL/ESL classroom prepares learners to use English in the world beyond based on their own needs, interests, and opportunities, and perform in an atmosphere of expression, interpretation, and negotiation of meaning from psycholinguistic and socio-cultural perspectives. Communicative language teaching (CLT) refers to both processes and goals in classroom learning. It is one of the most influential theoretical developments in language education as it helps redefine the objectives of foreign and/or second language instruction. This paper looks at the phenomenon of communicative language teaching (CLT) in the Moroccan EFL curriculum. It aims to study how CLT has been interpreted and implemented in various contexts examining teachers' attitudes. The data is gathered using semi-structured interview with EFL secondary level teachers. Based on the findings, respondents reflected positive attitudes showing that the use of CLT approach does enhance oral competency among students as well as learnerautonomy. However, teachers confirm that the EFL curriculum is barely emphasizing communication skills, which requires a curriculum reform and redesign in order to represent the $21^{\text {st }}$ century requirements and values.

Keywords: communication, curriculum, classroom, oral proficiency, learnerautonomy
\end{abstract}




\section{INTRODUCTION}

The status of teaching and learning English as a global language is increasingly gaining ground worldwide. Improving the English proficiency as a second and/or foreign language has become a priority in the field of education. Therefore, a wide range of initiatives have been taken. Various approaches and methods have been introduced and implemented aiming at enhancing the learning process of English among non-native speakers. Thus, in order to meet the challenges of the millennial era, a new approach has been put forth and received a worldwide recognition as the most dominant and innovative way to teach English as a second/foreign language. It is the communicative language teaching (CLT) approach. Content, syllabus, methodologies, outcomes, and assessment all serve to achieve the goal of communicative competence in the EFL/ESL classroom. Scholars, educators, and teachers acknowledge the adoption of the communicative language teaching in EFL/ESL curriculum in order to develop learners' English language competence. Littlewood (1981) argued that CLT has been introduced in the EFL/ESL instructional settings as a reaction to the traditional language teaching methods, aiming at improving students' learning proficiency and their ability to use English in real-life situations. However, despite the role that CLT approach plays in enhancing learners' oral proficiency, practitioners argue that both the curriculum and classroom practices do not reflect its theories and principles.

\subsection{Overview on the Implementation of English Language Teaching in Morocco}

English was first taught in Morocco during the era of the French protectorate. Teaching and learning English at that time was considered as "a purely functional instrumental tool" for economic purposes such as in tourism and international banking, and in higher education (Hyde, 1994). Colonization was afterwards replaced by the economic, technological, and linguistic domination. English language has internationally become the new imposed linguistic power (Holly, 1990). Thus, since its independence in 1956, Morocco has been working on developing new educational reforms aiming at improving the quality of education. The implementation of the English curriculum was one of the first projects the country launched as part of the National Charter for Education and Training in 1999 (Bedmar, 2014). The latter suggested a set of pedagogical guidelines to EFL teaching (M.E.N, 2009). These guidelines have focused on incorporating learnercenteredness as one of the main features of the EFL classroom, by adopting new approaches namely, the competency-based approach, communicative approach, and standard-based approach (M.E.N, 2009). However, despite all the efforts made to develop the EFL implementation in the Moroccan educational context, it is still lagging behind and unable to meet the millennial challenges (MATE, 2016).

Therefore, the Moroccan Supreme Council for Education and training has established a roadmap for reform, teaching foreign languages in particular. Since it is recognized as the world's most recognized language for communication and the language of science and technology, Morocco has set a number of measures and policies to improve the teaching and learning of English language aiming to empower its educational, political, and economic domains (MATE, 2017). A matter 
of fact, to keep up with the 21st century global and ever-increasing connections, Moroccan students are in need to acquire some fundamental linguistic skills and be aware of the different cultural and behavioral perspectives of the other. According to the pedagogical guidelines for English language teaching in Morocco set by the Ministry of National Education, teaching EFL is based on an instructional program that encourages the student to communicate internationally and go beyond this knowledge to develop real-life uses for foreign languages. For this purpose, the reform has underlined the importance of a far-reaching shift at the level of the fundamental strategies and techniques of EFL teaching and learning. The EFL instructional setting should essentially engage both teacher and students. The former is no more considered a source of knowledge, but a guide a facilitator. On the other hand, the student is asked to develop his/her learning autonomy and possess some basic skills mainly critical thinking and problem-solving.

\subsection{Purpose of the Study}

This study is an attempt to look at the phenomenon of communicative language teaching (CLT) in the Moroccan EFL curriculum. It aims to investigate the extent to which CLT is introduced and incorporated in various contexts in the EFL classroom shedding light on teachers' believes and attitudes. For this purpose, this research uses a semi-structured interview with 16 EFL secondary level teachers.

\subsection{Research Questions}

In order to address the purpose stated above, the following research questions were generated:

- What are the attitudes of the Moroccan EFL teachers regarding the use of CLT approach to enhance oral competency among students?

- What sort of activities do EFL teachers use in their classrooms to promote their students' oral proficiency?

- What challenges impede the integration of the CLT approach in the EFL Moroccan context?

\subsection{Significance of the Study}

The current study attempts to investigate the implementation of the communicative language teaching in the Moroccan EFL classroom based on EFL teachers' perceptions. This study is significant theoretically and practically. As far as the theoretical importance is concerned, it tries to explore the teachability of the communication model from the point of view of the teachers whereas most other studies have been concerned with learner variables. In terms of the practical and pedagogical significance, the findings of this study may be helpful to educational institutions and stakeholders involved in EFL teaching and learning in order to develop the quality of the latter.

The literature given in this research highlights the main and recent trends in communicative language teaching research and related theories. After summarizing the existing literature, the paper presents the findings of the interview examining EFL teachers' perceptions regarding CLT implementation in the Moroccan EFL 
curriculum. The qualitative findings suggest that EFL teachers believe in the use of CLT approach to enhance oral competency among students as well as learnerautonomy. However, respondents state that the EFL curriculum is barely emphasizing communication skills, which requires a curriculum reform and redesign in order to represent the 21 st century requirements and values.

\section{LITERATURE REVIEW}

As EFL teaching and learning focuses on a great potential communicative competence, an approach has emerged and been recognized worldwide as the dominant model for language education; it is the communicative language teaching (CLT) approach (Richards, 2013). The latter provides a framework that integrates language theory and teaching practice (Savignon, 1991). The communicative language teaching approach applies particularly to the present study, aiming to investigate the EFL secondary level curriculum focusing on the communicative teaching and learning techniques.

\subsection{The Communicative Language Teaching (CLT) Approach}

Emphasizing the communicative competence is one of the most influential developments in language education. Hymes (1972) defines communicative competence as the "aspect of our competence that enables us to convey and interpret messages and to negotiate meanings interpersonally within specific contexts" (as cited in Mulat, 2003, pp. 10-11). In other terms, communication competence is the knowledge that helps a speaker to appropriately and functionally use a specific language or a linguistic system within a speech community. Based on the communicative competence, the communicative language teaching approach emerged in the early 1980s in Britain and spread throughout the world as an effective approach in second and foreign language instruction, English in particular (Liao \& Zhao, 2012; Ozsevik, 2010). The CLT theory arose as a reaction to the traditional grammar-based model to teaching and learning which puts emphasis on materials, syllabi, and teaching methods (Richards \& Renandya, 2002).On the other hand, the communicative language teaching approach is meaning-oriented (Hedge, 2000). Research confirms that learners tend to better learn a foreign language when their attention is focused on the meaning rather on the linguistic form. For instance, Krashen and Terrell's (1983) state that in order to enhance students' foreign language acquisition, teachers should provide sufficient communication input and opportunities in a psychologically non-threatening environment. However, Savignon (2002a) argues that "communicative language teaching does not necessarily mean total rejection of familiar materials [grammar]" (p. 7). CLT gives recognition to both fluency and accuracy in language teaching and learning. Additionally, Canale and Swain (1980) point out that both linguistic and communicative competence are fundamental in language teaching and learning, ESL/EFL in particular. They further explain that communicative competence is based on the interaction between the grammatical competence and knowledge and the socio-linguistic competence and knowledge. That is, in order to communicate efficiently, it is important to know what to say, how to say it, and when to say it. 
Today's education is increasingly interested in the empowerment of learners' skills such as critical thinking, problem-solving, cooperation, and creativity, deemed necessary to meet the $21^{\text {st }}$ century requirements. In this regard, educators like Brown (2000) and Savignon (1991, 2002a) assert that underscoring the communication competence in language curriculum allows learners to perform in an atmosphere of expression, interpretation, and negotiation of meaning from psycholinguistic and socio-cultural perspectives. CLT is a multidisciplinary perspective that builds on several disciplines including linguistics, psychology, philosophy, sociology, and education. According to Savignon (2002b), the CLT model is based on incorporating methodologies and pedagogies that can better engage learners in functional and authentic use of language for meaningful purposes. Besides, Trim (2012) explains that the development of the CLT approach was the result of a number of discussions about how to produce a new curriculum that reflects and puts into practice the theories of communicative competence, speech acts, and notional analysis in language instruction.

Nowadays, syllabi for language teaching and learning emphasize on establishing a systematic and comprehensive coverage of the different components of communicative competence, including language skills, content, grammar, vocabulary, and functions. The communicative approach involves teaching and learning a language in order to be used in real-life situations. That is, learners learn a language to communicate in their day-to-day experiences. The CLT approach, thus, provides students with countless opportunities to be involved in communicative events in using the language. The implementation of communicative activities in ESL/ESL classroom, such as role plays, simulations, situational dialogues, games, projects, and problem solving, prepares learners to use English in the world beyond based on their own needs, interests, and opportunities. Such activities allow students to expand their linguistic knowledge by creating meaningful interactions, negotiating meaning, and learning through feedback. Hence, including these practices in the curriculum can empower students' receptive and productive skills which are highly recommended to achieve a quality education in the millennial age (Thongwad, 2011). A matter of fact, CLT puts focus on the learner and aims at preparing them for lifelong learning by promoting their ability to control and organize their own learning inside and outside the school context. On the other hand, the teacher's role remains important as a facilitator, advisor, and monitor (Littlewood, 1981). In CLT, the role of the teacher is perceived to be less dominant; the teachers' role changes from transmitter $\mathrm{f}$ knowledge to a mentor and a cocommunicator. With this transformation, students are expected to become managers of their own learning. In other terms, in the CLT context, the teaching-learning process becomes student-centered rather than teacher-centered, as learners play the key role in a large proportion of the learning process.

Moreover, according to the literature, the CLT model believes in the importance and effectiveness of technology use in teaching and learning. As stated earlier, curriculum reform advocates innovation at the level of educational methods and tools notably through the usage of ICTs in instructional settings. Technology has the potential to support oral proficiency by creating an environment for 
interactive, authentic, reflective, and collaborative activities. The integration of multimedia technology enhances the EFL teaching and learning in general, and provides students with great incentives for communication. Shayamlee and Phil (2012) argued that the use of technology with communicative activities like group discussions, debates, public speaking, and games can inspire students' positive thinking and communication skills.

\section{RESEARCH METHODS}

This section deals with the implemented research methodology employed to collect and analyze data in this study. First, it describes the overall research design including the sampling procedure, research setting and data collection instruments. The second section presents a brief view on the analysis and interpretation process.

In order to examine the adoption of the communicative language teaching (CLT) approach in the Moroccan EFL classroom, this paper relies on a qualitative research method which is semi-structured interviewing. The latter is defined as a guided conversation that includes a set of predetermined themes and topics, but at the same time it allows some elaboration in the questions and answers (Creswell, 2009). Hence, as this inquiry aims to study teachers' attitudes, the semi-structured interview is conducted to allow participants to freely express their views and elaborate more on the issues in question.

Before embarking on interviewing respondents, the latter were asked to give informed consent explaining the importance of their feedback to the study. Some teachers expressed their agreement to answer to questions immediately. Some others were reluctant but they finally accepted to respond. In total, 16 EFL teachers were interviewed. Confidentiality of the data was maintained and respondents' names were not included as part of the survey procedure. Participants were selected based on a non-probability sampling method. The interviewees were teachers of English in some secondary schools located in Fes city. The sample size was 16 where 10 were females and 6 males (see table 1). Interviews were administered in February, 2018 and each interview lasted between 20-30 minutes and was recorded. Interviews, after being conducted with the $16 \mathrm{EFL}$ teachers, were transcribed and typed into Microsoft Word. Subsequently, each question within the interviews was analyzed. The interview questions analysis focused on coding and categorizing patterns of the data to identify meanings and themes. The purpose behind this process is to formulate a coherent structure of data and ensuring reliability.

Table 1. Participants' Gender Distribution

\begin{tabular}{|c|c|c|}
\hline Gender & Frequency & Percentage \\
\hline Male & 6 & $37.5 \%$ \\
\hline Female & 10 & $62.5 \%$ \\
\hline
\end{tabular}

\section{RESULTS AND DISCUSSION OF FINDINGS}

As stated earlier, this study is an attempt to analyze the implementation of the communication language approach in the Moroccan EFL classroom, focusing on teachers' attitudes. The following section presents the findings emanating from the interviews conducted with secondary level EFL teachers. 
The findings are discussed based on the following research questions:

- What are the attitudes of the Moroccan EFL teachers regarding the use of CLT approach to enhance oral competency among students?

- What sort of activities do EFL teachers use in their classrooms to promote their students' oral proficiency?

- What challenges the integration of the CLT approach in the EFL Moroccan context?

Basically, the totality of respondents believed in the important role that CLT approach plays to enhance oral competency and also language proficiency among EFL students. Teachers explained that adopting the communicative approach in the EFL classroom helps in creating an atmosphere where students are actively participating and using the target language. EFL teachers agreed that using the communicative approach while teaching leads their learners to become more responsive and engaged in lessons. According to respondents, the CLT increases students' interaction and participation in the classroom as well as it enhances their engagement and socialization. For instance, a female teacher stated that "while using the communicative approach in teaching, students show more self-confidence and self-esteem as they feel more in charge of their own learning". That is, the CLT approach tends to increase learner autonomy. In this regard, Littelwood (1981) pointed out that the use of the communicative model in language teaching improves students' classroom performance and motivation, as well as it provides opportunities for positive personal relationships to develop among students and between students and teacher. Moreover, according to teachers' responses, CLT encourages cooperative language learning. They stated that CLT activities such as pair and group work and role play allow low proficiency students to actively participate in classroom. In the same line of thought, Johnson, Johnson, and Smith (1991) argued that cooperative learning is placed at the heart of the communicative approach as it encourages and promotes the maximum use of group learning activities which develops students' learning autonomy, interaction, exchange of information, cooperation, and competition. Moreover, half of the respondents underscored the prominent role of increasing English language oral proficiency in the millennial era. They said that focusing on the communicative skills inside the classroom will help learners acquire the language they will need in order to deal with real-life situations. Other teachers commented that being proficient English language speakers and communicators is mandatory in the $21^{\text {st }}$ century academic and professional careers. A respondent explained that nowadays student are increasingly in need of using English in communication in order to succeed as professionals. In addition to promoting learners' language acquisition, respondents referred to the effectiveness of the communicative model in enhancing their role as EFL teachers. They maintained that emphasizing communicative paradigms helps the teacher perform as a facilitator and mentor instead of dominating the classroom. For instance, a teacher said that "adopting communicative strategies helps me perform in better conditions inside the classroom as it becomes an enjoyable, interactive, and interesting place both for me and my students". 
On the other hand, in order to evaluate the extent to which the communicative approach is manifested in the Moroccan EFL curriculum in high school, teachers were asked if communication skills are emphasized in the curriculum. Teachers affirmed that the current EFL curriculum barely promotes the communication skills. They further explained that teaching EFL in the secondary level is still approached using traditional paradigms. The majority of respondents pointed out that the curriculum is outdated and does not aim to provide contents that target skills' developments. Similarly, while investigating the incorporation of CLT in the Chinese EFL context, Daisy (2012) found that the existing syllabi abides by traditional teaching and learning paradigms and do not reflect the objectives of CLT. Subsequently, all teachers asserted that the EFL curriculum is not promoting the $21 \mathrm{st}$ century, the communicative proficiency in particular. They argued that the teaching methods, teaching theories, and teaching materials do not contribute to the development of the communicative and oral competence of EFL learners. Teachers, as implementers of the curriculum, are more concerned with how much content they should deliver than how effectively this content can be used to develop learners' skills. Teachers confirmed that the curriculum is based on an examination-oriented policy. That is, EFL teaching and learning focused on providing students with as much information as possible just to pass examinations. Teachers, therefore, commented that the EFL curriculum focuses on the skills of reading and writing more that the mastery of language skills and the development of students' communicative competence.

Furthermore, the interview attempted to highlight the main activities that take place in the EFL classroom from a communicative perspective. Respondents referred to two main activities, namely dialog and role play. Teachers stated that such activities are included in the textbook in order to practice some grammar lesson, such as the use of the present perfect, use of modal verbs, reported speech, among others. According to respondents, the communicative activities do not serve for interaction, expression, and negotiation. They are mainly used for grammatical competence. In Bangladesh, Hamid and Baldauf (2008) argued that despite the fact that CLT is emphasized in the new textbooks, it can be argued that this focus is ignored, and texts are generally used like the old grammar-translation texts. However, some few teachers said that they try to develop their students' communicative and oral proficiency by asking them to prepare presentations and perform them inside the classroom in front of their classmates. These teachers claimed that such activities allow students to work on their stage-fright and gain more self-confidence, also, they enable them to interact and share their opinions using the target language. Other teachers said that they use group discussions. They reported that during group discussions students feel motivated to use English in communicating their real-life situations. Respondents explained that adopting the communicative approach connects between students' in-school learning activities and their out-of-school situations. Kowalska (1991) believes that communicative activities like role-play and pair and group work develop learners' fluency in speaking. Such activities help students develop the language deemed necessary to be used in real situations and social relationships more than a language for the 
classroom. Other teachers use interactive games, which, according to them, stimulate their students' inductive and discovery learning.

As stated in the review of the literature, ICT use is one of the main factors of the CLT model; therefore, respondents were asked about their classroom ICT use, and to what extent this use can support their learners' English language oral proficiency. The majority of the interviewees said that they do not use ICTs in their classroom because the schools where they teach are not equipped with technological tools. Similarly, while exploring ICT use in teaching EFL in higher education, Laabidi (2017) found that ICT use by professors strongly and significantly correlate with institutional support. That is to say, EFL teachers and professors' lack of ICT implementation in the classroom decreases because of the absence of organizational support both in terms of materials and professional training. A matter of fact, Morocco as a developing country, does not have adequate technological facilities and support, which negatively affect the implementation of such innovative approaches in the school sector. The majority of the institutions, as claimed by the interviewees, are not equipped with modern teaching aids, and still use age-old blackboard and chalk in classrooms as they even do not have whiteboard and marker facilities. Some few teachers stated that they sometimes use their own computers and data show if available. These teachers affirmed that, in fact, the use of technology can influence their students' oral production as it stimulates both their visual and auditory senses and provides them with effective and practical learning opportunities. For instance, a teacher said "I often use my computer with the data show projector for some icebreaking pair and group activities. My students always show interest and feel more motivated to interact between each other"

Subsequently, respondent-teachers were asked about the main challenges that may impede the incorporation of the communicative language teaching in the Moroccan EFL classroom. Teachers stated that the main issue to developing students' communicative competence is students themselves. They asserted that the majority of students learn with a low intrinsic motivation because they think that the English language is not necessary to their needs since it is not part of their daily life. According to teachers, students refuse to communicate and take part in classroom interactions. Another group of teachers commented that CLT is not manifested in the EFL classroom because of some teachers' lack of awareness and understanding of this new and innovative approach. A respondent explained that there are some teachers who strongly believe in the traditional teaching approaches and methods which emphasize accuracy more than fluency. These teachers, as stated by the interviewees, suffer from deficiencies in oral English teaching strategies which negatively influences on their students' communicative competence. Accordingly, Savignon (2002a) said that some teachers feel frustrated and not at ease to use the communicative approach in their teaching because, in their opinion, it lacks precision and does not provide them with universal scale for assessing their learners' achievement. Thus, as interviewees commented, the lack of effective teacher training courses is one of the main causes that hinder the successful implementation of the CLT approach in the EFL classroom. Similarly, Mowlaie and Rahimi (2010) attempted to study teachers' attitudes towards using the CLT in their 
classroom. Findings have showed that the surveyed teachers strongly believe in the potent role of the communicative approach; however, their classroom practice is not in harmony with their perception. The researchers have found that the main reason lies in the lack of enough training opportunities on CLT for teachers. Besides, teachers referred to class size as another challenging obstacle. They argued that using the communicative approach in an overcrowded classroom of more than 40 students makes the task very chaotic. A matter of fact, Larsen-Freeman (2000) confirmed that the implementation of CLT is always convenient for small groups in order to allow learners to interact, negotiate meaning, and better concentrate on meaningful communication, and thereby achieve authenticity and better quality in learning.

Finally and before wrapping up the interview, respondents were requested to give some of their suggestions and recommendations in relation to the issue in question. All teachers argued that the Moroccan educational system in general and EFL in particular require a drastic change at the level of teaching and learning approaches, methods, tools, and theories. Teachers, through this interview, raised their call for a real curriculum reform in order to meet the challenges of the $21^{\text {st }}$ century. They said that developing students' communicative proficiency in English should be one of the priorities in the Moroccan education. The EFL curriculum should be designed in accordance with students' needs and interests in order to stimulate their communicative skills. Besides, teachers recommended the inclusion of more communicative activities that would place the learner in the center of the process while the teacher becomes a facilitator and mentor. Furthermore, EFL teachers stated that a successful incorporation of such innovative approaches like the CLT requires a professional training in order to enhance their understanding and awareness as well as to provide them with the necessary tools and pedagogies that will serve them to act as agents of change. A teacher stated that "we should be frequently invited to take part in in-service trainings along with workshops and seminars to stay always updated with the latest approaches that can improve the quality of our EFL teaching and classroom performance".

\section{CONCLUSION}

This study has attempted to give a comprehensive insight on the extent to which the communicative language teaching approach is manifested in the Moroccan EFL classroom. Even though this research focuses on teachers' attitudes only, the findings would seem to be important and useful for other stakeholders in order to improve the EFL teaching and learning in the Moroccan school. This study may add to the knowledge of the various fields related to EFL education such as educators, curriculum developers, material designers, professional trainers, and future researchers in order to develop the quality of EFL education in the country.

Nevertheless, like all research projects, this study has some limitations. First, as this research employed a semi-structured interview, the sample was relatively small and clearly cannot be considered representative of all EFL teachers; therefore, it raised the issue about generalizability of findings. Besides, the use of semi-structured interview only might not be sufficient to obtain comprehensive data 
on CLT implementation in the EFL context. Future studies should build on quantitative research such as questionnaires. Also, classroom observations are advocated in order to investigate how the CLT approach is practiced in EFL instructional settings. Finally, this research was mainly concerned with teachers' perceptions as the only variable. Other inquiries should investigate students' attitudes regarding CLT incorporation and the extent to which this approach can enhance their English language oral proficiency.

\section{REFERENCES}

Bedmar, L. V. (2014). "Educational Reforms in Morocco: Evolution and Current Status". International Education Studies, 7(12), 95-105.

Brown, H. D. (2000). Principles of Language Learning and Teaching. Boston, Massachusetts: Prentice-Hall Inc.

Canale, M. \& Swain, M. (1980). «Theoretical bases on Communicative Approaches to Second Language Teaching and Testing". Applied Linguistics, 1, 1.

Creswell, J. W. (2009). Research Design: Qualitative, Quantitative, and Mixed Methods Approaches. (3rd Ed.). Thousand Okas, CA: Sage.

Daisy. (2012, February). "Communicative Language Teaching: A Comprehensive Approach to English Language teaching". Language in India, 12(2), 249- 265.

Hamid, M. O., \& Baldauf, R. B. (2008, September). "Will CLT Bail out the Bogged down ELT in Bangladesh?” English Today, 24(3), 16-24.

Hedge, T. (2000). Teaching and Learning in the Language Classroom. Oxford: Oxford University Press

Holly, D. 1990. 'The Unspoken Curriculum, or How Language Teaching Carries Cultural and Ideological Messages" in Harrison, B. (ed.) Culture and the Language Classroom (pp: 11-19). London: McMilan Modern English Publications.

Hyde, M. (1994) "The Teaching of English in Morocco: the Place of Culture". ELT Journal Volume 48/4 doi.org/10.1093/elt/48.4.295

Johnson, D. W, Johnson. R. T., and Smith, K. A., (1995), "Cooperative Learning and Individual Student Achievement in Secondary Schools", In J. E. Pederson and Digby, A. D. (eds.) Secondary Schools and Cooperative Learning: Theories, Models, and Strategies. New York: Garland Publishing.

Kowalska, B. (1991). Let them Talk in English. Warszawa: Wydawnictwo Szkolne i Pedagogiczne.

Krashen, S., \& Terrell, T. (1983). The Natural Approach: Language Acquisition in the Classroom. Oxford: Pergamon Press

Laabidi, H. (2017). "Critical Reflections on the Effective Implementation of ICTs in Moroccan Universities. ASIAN TEFL, 2(2).

Liao, J., \& Zhao, D. (2012). "Grounded Theory Approach to Beginning Teachers' Perspectives of Communicative Language Teaching Practice". Electronic Journal of Foreign Language Teaching, 9(1), 76-90. 
Littlewood, W. (1981). Communicative Language Teaching: An Introduction. Cambridge: Cambridge University Press.

MATE. (2016). New Education Reform: Alternative Pathways is Language Education. Proceedings of the 36th Annual Conference Fes, Morocco, 14-17 April, 2016

MATE. (2017). Innovating language education: What Influential Role of Teachers. Proceedings of the 37th Annual Conference Agadir, Morocco, 30 January- 02 February, 2017

M.E.N. (2007). English Language Guidelines for Secondary Schools: Common Core, First Year, and Second Year Baccalaureate: All Streams and Sections. Retrieved from http://www.men.gov.ma on July 15th, 2018.

M.E.N. (2009). Pedagogical Guidelines for English Language at Middle School: 3rd Grade. Retrieved from http://www.men.gov.ma on July 15th, 2018.

Mowlaie, B., \& Rahimi, A. (2010). "The Effect of Teachers' Attitude about Communicative Language Teaching on their Practice: Do They Practice what They Preach?". Procedia Social and Behavioral Sciences, 9, 1524-1528

Mulat, L. (2003). Teachers' Attitudes Towards Communicative Language Teaching and Practical Problems in its Implementation. Unpublished MA Dissertation, University of Addis Ababa.

Ozsevik, Z. (2010). The Use of Communicative Language Teaching (CLT): Turkish EFL Teachers' Perceived Difficulties in Implementing CLT in Turkey. Unpublished Masters Dissertation, University of Illinois at Urbana-Champaign

Richards, J. C. (2013). "Curriculum Approaches in Language Teaching: Forward, Central and Backward Design". RELC Journal, 44(1), 5-33.

Richards, J. C. \& Renandya, W. A. (2002). Methodology in Language Teaching: An Anthology of Current Practice. New York: Cambridge University Press.

Savignon, S. J. (1991). "Communicative Language Teaching: State of the Art". TESOL Quarterly, 25(2), 261-277.

Savignon, S. (2002a). Interpreting Communicative Language Teaching: Contexts and Concerns in Teacher Education. London: Yale University Press.

Savignon, S. J. (2002b). Communicative Language Teaching: Linguistic Theory and Classroom Practice. In S. J. Savignon (Ed.), Interpreting Communicative Language Teaching: Contexts and Concerns in Teacher Education (pp. 1-27). New Haven, CT: Yale University Press.

Shayamlee, S. D. \& Phil, M. (2012). "Use of Technology in English Language Teaching and Learning": An Analysis. International Conference on Languages, Media, and Culture. Vol33.

Thongwad, W. (2011). "The Role of Communicative Activities in Developing Proficiency in English Speaking in Thailand". International Journal of Communicology, 1(1), 55-58.

Trim, J. (2012). "The common European Framework of References for Languages and its Background: A Case Study of Cultural Politics and Educational Influences". In: Byram M, Parmenter L (eds) The Common European Framework of Reference: The Globalisation of Language Education Policy. Bristol: Multilingual Matters, 14-34. 